\title{
Wielding the past to voice the future: an exploration of Indigenous Australians' sustained call to be heard
}

\author{
Joseph Khan \\ University of Technology Sydney, Faculty of Arts and Social Sciences, PO Box 123, Ultimo \\ NSW 2007, Australia. joseph.khan@student.uts.edu.au
}

\begin{abstract}
This essay explores why 'voice' has been a sustained desire for Indigenous Australians throughout history. By placing past efforts surrounding recognition, citizenship and self-determination on a continuum of progress, this text presents an argument for an unwavering, Indigenous voice to be enshrined in the Australian Constitution in order to serve the best interests of Aboriginal Australians.
\end{abstract}

Key words: Indigenous voice; self-determination; constitutional change; recognition; Indigenous representation

Since Federation there have been numerous propellants for an Indigenous 'voice' to become a foundation for institutional, legislative and social progress for Indigenous Australians. The calls for the establishment of an Indigenous voice have been a significant part of Aboriginal political history and have been a reasonable demand asking for a relatively small concession from governments that have consecutively denied Aboriginal people their most basic rights. As it stands, Australia's current constitution is antiquated and must be altered in order to enshrine an Indigenous voice that will combat the systemic oppression faced by Aboriginal people. Having historically faced endemic injustice at the hands of non-Indigenous powers, Aboriginal people have been left without just representation or self-determination. Through a historical lens, this essay discusses the demands that Aboriginal people have made over time for recognition, citizenship and self-determination; as well as examining how the desire for an Indigenous voice seeks to serve their best interests. The fight for citizenship rights by the Attribution 4.0 Unported (CC BY 4.0) License (https://creativecommons.org/licenses/by/4.0/), allowing third parties to copy and redistribute the material in any medium or format and to remix, transform, and build upon the material for any purpose, even commercially, provide $d$ the original work is properly cited and states its license. 
Australian Aboriginal Progressive Association, history of consultative government practice, truth telling and the demands of the Uluru Statement from the Heart are some aspects that will be examined in this essay to argue why incorporating Aboriginal-Australian perspectives into decision-making is non-negotiable in the fight for Indigenous justice.

The recognition of Aboriginal people's perspectives through a governmentally recognised body, such as the Australian Aboriginal Progressive Association (AAPA), sought to legitimise the fight for citizens' rights and drum the call for Indigenous justice. The AAPA was Australia's first politically recognised activist group made up of Aboriginal people and was formed in 1924 with the goals of disrupting the disadvantaged circumstances that plagued Aboriginal Australians as a result of political injustice that had developed over generations. Significant groundswell stirred from the AAPA's manifesto, which set out their claims, accusations and demands. The document took aim at several elements of governmental policy, including the Aborigines Protection Board, citizen rights and forcible removal of Aboriginal children. As per the AAPA's manifesto:

The arbitrary treatment which we receive from the A.P. Board reduces our standards of living below life-preservation point, which suggests that the intention is to exterminate us. In such circumstances it is impossible to maintain normal health. (Patten \& Ferguson 1938, p. 6)

By vocalising these concerns in their manifesto, the AAPA was able to contribute to the political discourse of the time in a way that conforms to non-Indigenous accepted modes of debate. Over the course of four years, the AAPA was a vocal institution that capitalised on media exposure and mobilised Aboriginal people within NSW to fight for the agenda that they set out to achieve. It is important to note 'the discourse that influenced the AAPA in the 1920s was black internationalism' (Maynard 2005, p. 20) and lent itself to the wider upheaval that was occurring in other countries against racially unjust institutions.

The ability for the AAPA to voice the concerns of Aboriginal people to those in power meant that a case could be made to wind back some of the oppressions that Australia's colonial regime had implemented in the years since occupation. The AAPA was formed by Aboriginal people, which meant that unlike previous activist groups that might have advocated for what change 'they' believed Aboriginal people needed, the Association was able to authentically represent the needs of their own people and voice their own terms of negotiation. Another example of how the AAPA acted a vessel for an Indigenous voice and was able to contribute to political discourse was through their activism regarding land rights. The systemic theft of Aboriginal reserves and prime land was a burning issue for the AAPA. As per Maynard:

The AAPA opposition to this land theft was blunt and to the point. They had land as their prime requisite, demanding enough land for every Aboriginal family in the State in order to provide economic independence (2005, p. 3) 
As examined in the above points, groups such as the AAPA that provide an Indigenous voice are imperative in communicating the needs of Aboriginals Australians in order to fight injustice through authentic representation.

The inclusion of a voice for Indigenous Australians in federal parliament and the pursuit of self-determination are symbiotic in their co-dependency for success. Self-determination in relation to Indigenous peoples dictates that they should be able to 'freely determine their political status and freely pursue their economic, social and cultural development' (United Nations 1966). Historically, the pursuit of any of the mentioned elements of selfdetermination have been mostly quashed by Australia's colonial regime as progress in this area comes at the cost of changing historical narratives to a truth-telling model. In the past, attempts at incorporating self-determination into policy effecting Indigenous people have been sparse and relatively unsuccessful. One notable step towards progressing towards selfdetermination was in the Mabo decision where 'for the first time in Australian law a form of Indigenous native title was found, not only to exist, but also to have predated and to have survived the acquisition of British sovereignty' (Dominello 2009, p. 2). By having an Indigenous Australian at the forefront of the fight, Mabo's authentic claim to land quashed the notion that terra nullius could be related to the Australian context. Furthermore, the decision to dismiss terra nullius and give validation to Indigenous ownership of land based off customary laws is in itself adherent to the principles of self-determination. If selfdetermination is to be successfully and consistently implied into policy-making, then including Indigenous perspectives are paramount in achieving this. Prior to the Mabo decision, the notion of self-determination was introduced to Australia's governmental discourse by Gough Whitlam in 1972 through the formation of the Aboriginal Land Rights Commission. The creation of a body made up of Indigenous people was set to encourage their self-determinative rights and saw a shift towards a progressive nuance that almost looked like self-governance. The aim was to:

Remove the disadvantages generally faced by Aboriginal Australians in the fields of housing, health, education, job training and employment opportunities, and to make it possible for Aboriginal communities and individuals to develop as they wish within the overall Australian Society. In all these fields, the importance of Aboriginal involvement and identity is paramount. (Sanders, 1982)

The succeeding Liberal government led by Malcolm Fraser in 1975 erased the words selfdetermination from government policy wording, and is one of many examples that demonstrate why the call for an enshrined Indigenous voice in federal parliament has been consistent throughout history. Touching on the 'cult of forgetfulness practised on a national scale' (Stanner 1968, p. 25), the sweeping under the rug of previous governments progress in relation to issues surrounding Aboriginal people acted to dismantle any movement towards real self-determination. The enshrining of a voice for Indigenous Australians in federal parliament would have ensured that history is portrayed honestly in various different social and legal mechanisms; thus, ensuring the principle of self-determination is at the forefront of the Indigenous agenda. 
The 1967 Referendum saw the political and organisational mobilisation of Aboriginal people that had seldom been seen in post-federation Australia, ultimately effecting changes to the constitution that would pave the way for a new chapter in political debate. The referendum was essentially a litmus test for the social conscience in Australia at the time, widely perceived as a defining moment of whether non-Indigenous Australians saw Aboriginal people as human or sub-human. The Australian public was put forward the question of whether they approved 'An Act to alter the Constitution so as to omit certain words relating to the People of the Aboriginal Race in any State and so that Aboriginals are to be counted in reckoning the Population' (Referendum 1967). Politically active groups of Indigenous Australians were behind the fierce momentum that resulted in a landslide 'Yes' vote, totalling 90.77\% (Attwood 1997, p. 55). The Federal Council for the Advancement of Aborigines and Torres Strait Islanders (FCAATSI) were a group of Indigenous Australians that spearheaded the campaign for the 1967 Referendum. They were able to effectively argue their case that the constitution was inequitable and created an unfair disparity towards Indigenous Australians and did so through the consistent and widespread petitioning leading up to the referendum. It is important to note that 'the 1967 Referendum was of symbolic significance, a collective statement of the Australian desire to include Indigenous Australians in a nondiscriminatory regime' (Rowse 2000, p. 20). This is yet another example of how a collective of Indigenous people working towards representation became a voice that kept nonIndigenous bodies of power in check. The sustained effort that this type of mobilisation is representative of should be one that transcends politics and reaches out to common decency. Righting wrongs of the past and working towards an inclusive future that takes into consideration Australia's First Peoples.

Although there were groups like FCAATSI that were imperative in securing the huge 'yes' vote, it is important to note that not everybody saw the referendum as a plight worthy of the amount of energy and focus that it received. Prominent activist Faith Bandler 'could not see how changing the Constitution was going to put bread into the mouths of Aboriginal people' (Bandler 1989, p. 81). Other Indigenous activists saw the need for greater emphasis on securing more significant changes such as sovereignty and rights to self-govern away from the iron-clad institutions of the colonial regime. Essentially, the push for Indigenous voices to be heard has been something that has sustained throughout each political movement because it has been born out of necessity. Without proper representation and consultation, governments will not be held to account over injustices that are put forward to Indigenous Australians. The 1967 Referendum was successful due to the influence of Indigenous voices in public discourse.

The Uluru Statement from the Heart is a document that leans on the culminated efforts of Indigenous activists over time and seeks to cement both participation of Australia's First Peoples and truth-telling as foundational aspects of future policy making through constitutional safe-guarding. Currently as it stands, the constitution allows for: 
The purposes of the last section, if by the law of any State all persons of any race are disqualified from voting at elections for the more numerous House of the Parliament of the State, then, in reckoning the number of the people of the State or of the Commonwealth, persons of the race resident in that State shall not be counted. (Constitution 1901)

This effectively allows states the power to ban people from voting based on their race, a gross example of the enshrined inequity that is instilled in Australia's most significant legal doctrine. The requests made in the statement are modest, thoughtful and staggeringly flexible as to the nature of their application. As it reads:

We call for the establishment of a First Nations Voice enshrined in the Constitution... We seek a Makarrata Commission to supervise a process of agreement-making between governments and First Nations and truth-telling about our history. (Uluru Statement from the Heart 2017)

Once again, emphasis is placed on truth-telling as a pillar of recognition and rightly so; progress will not concede to a falsified past. The Uluru Statement from the Heart is a mechanism that conforms to the modern context of legal change and with the right application of an Indigenous voice, would act to create a future that is foundationally more respectful and consultative in making decisions that affect Indigenous Australians.

As demonstrated through many different areas throughout this essay, history has shown that when non-Indigenous Australians have autonomy over Indigenous Australians, the result is likely to leave the latter worse off. Linda Alcoff theorises the limitations and growing rejection of speaking for others, she notes that:

Where one speaks from affects the meaning and truth of what one says, and thus that one cannot assume an ability to transcend one's location...this has an epistemically significant impact on that speaker's claims and can serve either to authorize or disauthorize one's speech. (Alcoff 1992, p. 7)

Applying Alcoff's mode of thinking to this context can be done seamlessly. How is a nonIndigenous government that has only their lived experience and 'location', whether that be a social location or structural location, able to speak authoritatively on behalf on group of people that they have in no way the ability to truly represent their best interests? They cannot. The demand for an Indigenous voice leans on Alcoff's questioning of representation and is such a significant issue because of the systemic failures that have plagued government after government when it comes to fighting for the rights of Aboriginal Australians. The Uluru Statement from the Heart is indicative of the sustained desire for Indigenous people to have their voice heard in a legitimised way.

Throughout Australia's post-colonial history, there have been countless desecrations of Indigenous Australians' rights with the key perpetrators being government bodies. In the face of these systemic injustices, there has been resistance and movements that have striven towards bettering the interests of Aboriginal Australians. This essay explored how fighting 
for citizen rights, calls for recognition through the 1967 Referendum, demand for selfdetermination and seeking enshrinement in the Australian Constitution have been active mechanisms in the call for a sustained Indigenous voice. Simply put, the call for an Indigenous voice has been one that has transcended time because of the need for selfrepresentation in order to best authentically communicate the social, political and cultural needs of Australia's First Peoples. By incorporating an Indigenous voice into decision making in Australia, truth-telling will be a pillar of the future and will seek to heal the wounds of the past by looking them in the eye and confronting them with compassion, honesty and recognition.

\section{References}

Alcoff, L. 1992, 'The Problem of Speaking for Others', Cultural Critique, No.20, University of Minnesota Press, pp 5-32.

Australian Parliament House, The 1967 Referendum, Created 25/05/2017, M.Thomas, accessed Monday 10th June 2019

<https://www.aph.gov.au/About_Parliament/Parliamentary_Departments/Parliamentary_Libr ary/FlagPost/2017/May/The_1967_Referendum>.

Australian Parliament House, Parliamentary Handbook, Referendums and Plebiscites: Constitutional Referendums, part 4, The Constitution, accessed Monday 10th June 2019, $<$ https://parlinfo.aph.gov.au/parlInfo/search/display/display.w3p; $d b=H A N D B O O K ; i d=h a n d b$ ook\%2Fnewhandbook\%2F2014-10-

31\%2F0048; query=Id\%3A\%22handbook\%2Fnewhandbook\%2F2014-10-31\%2F0000\%22>.

Patten, J. \& Ferguson, W. 1926, Aborigines Claim Citizens Rights!, 'The Publicist', Sydney pp 1-11, accessed Monday 10th June $<$ https://aiatsis.gov.au/sites/default/files/images/collections-andlibrary/collections/oe_dom/09/0902/0902.pdf >.

Bandler, F. 1989, 'The Referendum' in Turning the tide: a personal history of the Federal Council for the Advancement of Aborigines and Torres Strait Islanders, Canberra, Aboriginal Studies Press, pp.79-110.

Dominello, F. 2009, The Politics of Remembering and Forgetting: Native Title Law and Reconciliation in Australia, Cosmopolitan Civil Societies Journal, Vol.1, No.3 pp 3-31

Maynard, J. 2005, 'In the interests of our people: the influence of Garveyism on the rise of Australian Aboriginal political activism' in Aboriginal History, vol.29, Canberra: AIATSIS, pp.1-22.

Rowse, T. 2000, 'The Modest Mandate of 1967', Obliged to be difficult, Cambridge University Press, pp 17 - 33. 
Sanders, W. 1982, 'From self-determination to self-management', in P. Loveday (ed). Service Delivery to Remote Communities, ANU NARU Monograph, Darwin. 